\title{
Progressive Multifocal Leukoencephalopathy
}

National Cancer Institute

\section{Source}

National Cancer Institute. Progressive Multifocal Leukoencephalopathy. NCI Thesaurus.

Code C26815.

A progressive demyelination within the central nervous system associated with reactivation of a latent JC virus infection. 